\title{
Rationalization of the Use of Land and Capital Production Factors on Hybrid Cayenne Agriculture Business on Juwita Variety in Central Lombok District
}

\author{
I Dewa Gede Suartha' ${ }^{1)}$, Made Suma Wedastra ${ }^{2)}$, Ni Wayan Putu Meikapasa ${ }^{3)}$, \\ 4) I Gusti Ngurah Aryawan Asasandi, ${ }^{5}$ Ida Ayu Nopiari \\ Faculty of Agriculture, Mahasaraswati Denpasar University, Mataram Campus. \\ Amir Hamzah St,NTB 8313
}

\begin{abstract}
This study aims to determine the effect of land and capital production factors on the production of juwita hybrid cayenne varieties, and whether rational or not the use of land and capital production factors in the farming of juwita hybrid cayenne varieties in the Central Lombok regency. The research is carried out in Sintung, Belege and Bilebante Villages in Pringgarata Subdistrict, Central Lombok Regency, which have been selected using the purposive sampling technique, on the grounds that these villages have the highest productivity of juwita hybrid cayenne varieties compared to other villages. Furthermore respondents numbered 30 people who are determined by using proportional random sampling technique. Data are analyzed by using the Cobb-Douglas production function analysis which is changed to Logarithm Multiple Linear Regression. The results show that the area of land and capital jointly have a significant effect on the production of Juwita hybrid cayenne varieties cultivated by farmers in Central Lombok regency with an F-count of 255,690 and <Sig. 0.05, this means that the land and capital variable is able to explain the production variable by $95 \%(R 2=0.950)$. But only partially the land has a significant effect on the production of Juwita hybrid cayenne varieties with t-count $(18,975)<$ Sig. 0.05 . While capital has no significant effect on the $95 \%$ level of significance with t-count (0.679)> Sig. 0.05. This condition emerges because the added capital in the cultivation of Juwita hybrid cayenne varieties farming is not well targeted. Both land and capital are partially rational, and their production elasticities are between 0 1 and are in production area II (stage II).
\end{abstract}

Keywords:- Rationalization, Production Factors, Farming, Hybrid Cayenne, Juwita Varieties.

\section{INTRODUCTION}

One of the important agribusiness sub-systems that is capable of moving the economy of rural communities is agricultural business. Agricultural business activities can be carried out if there are factors of production that support it. Two factors of production which are considered capable of driving agricultural business activities include land and capital. Land is needed in agricultural business activities as a growing medium for plants used as business. While capital is needed to finance the operational activities of agricultural businesses.

The influence of these two factors of production can be seen in terms of quantity and quality. From the quantity aspect, the wider the arable land, the higher the production yielded. While in terms of quality the more complete the nutrients contained in arable land, the higher the production produced by the land.

The results of research [1] in Nangsri Village, Manisrenggo Subdistrict, Klaten Regency on factors influencing the production of cayenne pepper stated that seedlings, land area, manure, phonka fertilizer, family laborers and non-family workers outside the family influence on the production of cayenne pepper. A different matter was found by [2] in their study of the factors affecting the production of red cayenne farming in Tapenpah village, Insana subdistrict, North Central Timor regency, that land and capital partially has no significant effect on red chilli production. This can be said that land and capital may not yet provide optimal results.

In addition to land, capital is also needed in farming activities to accelerate those programs. Without capital, other factors of production cannot be organized to produce a product. The amount of capital required depends on the type of commodity being cultivated.

In the theory of production it is stated, each producer always behaves rationally in using the available resources to produce in order to be able to bring results that are in line with expectations, namely maximum profit. In other words the factors of production used have a relationship with the products produced.

Central Lombok Regency is one of the second-level regions of West Nusa Tenggara Province which has a vision of the realization of modern, resilient and efficient agriculture towards a prosperous society. This vision will be achieved through its mission of mobilizing various efforts to optimally utilize agricultural resources in empowering independent, advanced and prosperous agribusinesses [3]. 
Furthermore [3], stated in line with the mission of agricultural development mentioned above, increasing food production has an important meaning in enhancing the standard of living, intelligence and welfare of the community. Increasing food production does not only depend on staple crops, but also horticultural crop production, especially vegetables and fruits.

One of the horticultural commodities that attracts attention in the Central Lombok Regency is the Juwita hybrid cayenne variety commodity. Within five years (2012-2016) the development of planting area and productivity of Juwita hybrid cayenne variety commodity in this area shows fluctuation with an average land productivity of 1.79 tons per hectare. If this productivity is compared with the chilli productivity achieved by the Farmers Cooperation Forum, which is 14.6 tons per hectare, the productivity achieved by farmers in Central Lombok Regency is still relatively lower [4].

The emergence of this phenomenon, is probably due to the lack of rational use of land resources and capital in the farming activities of Juwita hybrid cayenne variety in Central Lombok Regency?

\section{$>$ Formulation of The Problem}

Based on the description of the problem above, the problem can be formulated as follows:

- Does the area of land and capital affect the production of cayenne produced by farmers in Central Lombok Regency?

- Is the area of land and capital used in the Juwita hybrid cayenne variety farming activities rational or not?

\section{$>$ Research Purposes}

- To find out the influence of land area and capital on the production of Juwita hybrid cayenne variety produced by farmers in Central Lombok Regency.

- To determine the whether rational or not the use of land and capital in the Juwita hybrid cayenne variety farming activities by farmers in Central Lombok Regency.

\section{Assumptions}

To direct this research in the right direction, the following assumptions need to be determined, including:

- Land and capital are considered as variable production factors and other factors of production are fixed.

- Skills that are owned by Juwita hybrid cayenne variety farmers are considered the same.

\section{RESEARCH METHODS}

\section{A. Types of research}

This research is classified as descriptive research. [5] says descriptive research focuses on the actual problem as it is at the time the research takes place. Through this type of research, researchers try to describe the events that are the center of attention without giving special treatment to those events.

\section{B. Determination of Research Locations}

This research is conducted in Pringgarata sub-district, Central Lombok regency. The selection of Pringgarata subdistricts is carried out purposively based on consideration that the Pringgarata sub-district has the highest level of productivity than the others. Based on the same considerations, three villages in Pringgarata subdistrict are selected, namely Sintung village, Bagu village, and Bilebante village.

\section{Determination of Respondent Methods}

Determination of respondents in each village is carried out using proportional random sampling of $40 \%$ of 75 farmers who work on Juwita hybrid cayenne variety in the three villages. Thus the number of respondents selected is 30 people, consisting of 10 people in Sintung village, 12 people in Bagu village, and 8 people in Bilebante village. In detail the determination of respondents is presented as Table 1.

\begin{tabular}{|c|c|c|c|}
\hline No. & Village & $\begin{array}{c}\text { Farmers } \\
\text { Population }\end{array}$ & $\begin{array}{c}\text { Respondents } \\
\text { (orang) }\end{array}$ \\
\hline 1 & Sintung & 25 & 10 \\
\hline 2 & Bagu & 30 & 12 \\
\hline 3 & Bilebante & 20 & 8 \\
\hline \multicolumn{2}{|c|}{ Total } & 75 & 30 \\
\hline
\end{tabular}

Table 1:- Determination of Juwita variety Hybrid Chili Respondent Respondents in Pringgarata District, Central Lombok Regency

Source: BPP Pringgarata District, 2019

\section{Method of Collecting Data}

Data collection is done by direct interview method, namely interviewing selected respondent farmers with a list of questions (questionnaire) prepared in advance.

\section{E. Data Analysis :}

$>$ Data Analysis: Effect of land area and capital on the production of Juwita hybrid cayenne variety with the following stages:

- Modeling: functional relationship between production and land production factors and capital as a variable production factor in the cultivation of Juwita variety hybrid cayenne expressed in the Cobb-Douglas function model by the OLS (Ordinary Least Square) method as follows [6] :

\section{$Q=$ boX1b1X2b2e}

where: $\mathrm{Q}=$ chili product $(\mathrm{kg})$, bo $=$ intercept, $\mathrm{b} 1, \mathrm{~b} 2=$ regression coefficient, $\mathrm{X} 1=$ soil

$\mathrm{X} 2$ = Capital, $\mathrm{e}=$ error

The exponent function above can be changed to a double log linear function with the logarithm transformation as follows: $\log \mathbf{Q}=\log \mathbf{b o}+\mathbf{b 1} \log \mathbf{X} 1+\mathbf{b 2}$ $\log \mathrm{X} 2+\log \mathrm{e}$.

If $\log \mathrm{Q}=\mathrm{Y} ; \log \mathrm{b} 0=\mathrm{b} 0 * ; \log \mathrm{X} 1=\mathrm{X} 1 * ; \log \mathrm{X} 2=\mathrm{X} 2$ *; $\log \mathrm{e}=\mathrm{e}^{*}$; then the equation becomes: $\mathrm{Y}=\mathrm{bo}{ }^{*}+\mathrm{b} 1 \mathrm{X} 1$ $*+\mathrm{b} 2 \mathrm{X} 2 *+\mathrm{e}^{*}$ 
- Model Testing: using the SPSS program. 17

$\checkmark$ Classical Assumption Test: [7]

- Normality Test: conducted to find out whether the data taken is from a normal distribution population or not. If the Sign value $>0.05$, it can be concluded that the data is normally distributed or vice versa.

- Multicollinearity Test: conducted to see the occurrence of collinearity between independent variables in the model. If Tolenrance value $>0.1 \&$ VIF $<10$, then it can be concluded that multicollinearity or vice versa.

- Heteroscedasticity test: with the Glejser test, which is to see the difference in variance of the residuals for all observations in the linear regression model. If the Sign value $>0.05$, then the conclusion does not occur heteroscedasticity or vice versa.

\section{Statistic test :}

- R2 test is used to see the accuracy of the model used and expressed in percent dependent variables can be explained by the independent variables entered into the model. If R2 $=1$ or close to 1 , then the model is considered good or vice versa.

- F test (Over All Test) is used to determine the effect of aggregate independent variables on the dependent variable. If the Sign value> 0.05 , then it is concluded that the independent variables in the aggregate have a significant effect on the dependent variable or vice versa.

- Individual $t$ test is used to know the effect of each independent variable partially on the dependent variable or vice versa.

- Rationalization Analysis: using production areas: [8], namely:

$\checkmark$ If production is in area II, then production activities are considered rational.

$\checkmark$ If production is in regions I \& II, then the production activity is classified as irrational

\section{RESULTS AND DISCUSSION}

\section{A. Production and Production Costs}

The average area of land cultivated by the respondent farmers is 0.303 hectares with the production of Juwita hybrid cayenne varieties averaging $643.8 \mathrm{~kg}$ or $2,124.75 \mathrm{~kg}$ / hectare. While the average production per production factor is the APP (Average Physical Product) of land = $2,124.75 \mathrm{~kg} / \mathrm{hectare}$. If the average production achieved by respondent farmers in Pringgarata sub-district, Central Lombok regency is compared with the average production of 5 tons per hectare in West Nusa Tenggara in 2017, then the production achieved by respondent farmers is very low. The low production of Juwita hybrid cayenne variety achieved by responsive farmers is probably due to the imperfect implementation of Juwita hybrid cayenne variety cultivation technology at the respondent farmer level due to the education level of the respondent farmers is still relatively low. The other side of the average capital cost per unit is Rp. 705,833.33, - with APP capital of $0.001 \mathrm{~kg}$.

\section{B. The Influence of Land and Capital on The Production of Cayenne Pepper in Pringgarata District, Central Lombok Regency}

The connection between factors of production with production is often expressed in the form of a production function. In practice, the use is still influenced by factors outside human control, so that the production function is known as the uncertainty factor. The selection of the production function is adjusted to the problem of interest, so that it can provide complete information. Relation with the aim to determine the effect of land and capital production factors on the production of Juwita hybrid cayenne pepper varieties of respondent farmers in Pringgarata sub-district, Central Lombok regency, the Cobb-Douglas production function is used. This CobbDouglas function can be solved by regression, so that the rules that apply to the regression line also apply to the Cobb-Douglas production function. The form of the CobbDouglas function used is:

$$
\mathrm{Q}=\mathrm{boX} 1 \mathrm{~b} 1 \mathrm{X} 2 \mathrm{~b} 2 \mathrm{e}
$$

where: $\mathrm{Q}=$ chili products $(\mathrm{kg})$; bo = intercept; b1, b2 = regression coefficient; X1 = land $(\mathrm{Ha}) ; \mathrm{X} 2$ = Capital (Rp.); $\mathrm{e}=$ error

Before the cob-Douglas function is used to predict the correlation between the factors of land production and capital on the production of juwita hybrid cayenne varieties of farmers in Pringgarata sub-district, Central Lombok regency, the model is first tested with classic assumptions.

The results of the classical assumption test analysis using SPSS. 17 obtained:

- Normality Test: with Kolmogorov Smirnov, obtained Asymp. Sig. (2-tailed) of 0.08. This value is greater than Sig. 0.05, so it can be concluded, that the research data are spread normally.

- Multicollinearity Test: with the help of SPSS. 17 values obtained for Tolenance and VIF (Variance Inflation Factor) are respectively Tolerance $=0.731$ and VIF $=$ 1.368. Tolerance rate of 0.738 is greater than 0.1 and VIF of 1.368 is smaller than 10 , so it can be concluded that the model does not experience multicollinearity.

- Heteroscedasticity test using the Glejser method using SPSS. 17 obtained that Sig. land and capital $(0.463$ \& 0.519 ) is greater than 0.05 , so it is concluded that there is no heteroscedasticity in the model. Because the model meets classic assumptions, the model can then be used to predict the influence of land and capital production factors on the production of Juwita hybrid cayenne varieties by respondent farmers in Pringgarata sub-district, Central Lombok regency. In summary the results of the statistical test analysis with the help of the SPSS Program. 17 can be presented as in Table 2 below: 
ISSN No:-2456-2165

\begin{tabular}{|c|c|c|c|c|}
\hline Independent Variable & $\begin{array}{c}\text { regression } \\
\text { coefficient (bi) }\end{array}$ & Standard error & t-count & Sig. \\
\hline Constanta (log bo $=\log 3.167)$ & 0.501 & 0.203 & 15.574 & 0.000 \\
\hline Land (X1) & 0.905 & 0.048 & 18,975 & 0.000 \\
\hline Capital (X2) & 0.020 & 0.030 & 0.679 & 0.503 \\
\hline \multicolumn{2}{|c|}{ F-count $=255.690$} & 0.000 \\
\hline
\end{tabular}

Table 2:- Analysis of The Research Data of Respondents in Juwita Hybrid Cayenne Variety Farmers in Pringgarata Sub-district, Central Lombok Regency, 2020

From Table 2 above it appears that the value of R2 = 0.950 and F-count $=255.690$ (Sig. $0.00<0.05$ ). These figures indicate that in aggregate $95.0 \%$ of the production of Juwita hybrid cayenne varieties cultivated by respondent farmers in Pringgarata sub-district, Central Lombok regency can be explained by factors of land and capital production. While the remaining $5 \%$ is explained by factors not included with the $95 \%$ confidence level.

From Table 2. above it can also be formulated the form of production functions of Juwita hybrid cayenne variety respondent farmers in Pringgarata sub-district, Central Lombok regency as follows:

$\log \mathrm{Q}=\log 3,167+0,905 \log \mathrm{X} 1+0,020 \log \mathrm{X} 2+\log \mathrm{e}$ or $\mathrm{Q}=0.500648 \mathrm{X} 10,905 \mathrm{X} 20,020 \mathrm{e}$

From Table 1. above it can also be explained partially, that the influence of land and capital production factors on the production of Juwita hybrid chilli varieties respondent farmers in Pringgarata subdistrict, Central Lombok regency includes:

\section{$>$ Land Production Factors}

Land production factors significantly affect the production of cayenne pepper farmers in the Pringgarata sub-district of Central Lombok regency at a 95\% confidence level (Sig. <0.05). Regression coefficient of 0.905 shows the elasticity of production factors of land production to the cayenne production of respondent farmers, meaning that if the arable land area increased by $1 \%$ will increase the production of of Juwita hybrid cayenne variety of respondent farmers by $90.50 \%$. In other words, the greater the area of land cultivated, the higher the production of Juwita hybrid cayenne variety produced by respondent farmers in Pringgarata sub-district, Central Lombok regency. Similar opinion is also expressed by [9] that labor, capital, and land area have a positive effect on the production of lowland rice farming in Rowosari district, Kendal regency.

\section{Factors of Capital Production}

The capital production factor had no significant effect on the production of cayenne pepper which was undertaken by the respondent farmers in Pringgarata sub-district, Central Lombok regency at a 95\% confidence level (Sig.> $0.05)$. The regression coefficient of 0.020 shows, the elasticity of production of capital production factors which means that with the addition of capital by $1 \%$ and other factors of production remain, it will happen to increase production by $2 \%$. This increase is not statistically real. This might be caused because the added capital to buy agricultural production facilities is used not on target, for example eradicating pests and diseases excessively, thus damaging the growth and production of Juwita hybrid cayenne varieties cultivated by respondent farmers.

In contrast to the results of research conducted by [10] on the analysis of factors affecting Arabica coffee production in South Sulawesi and the results of [11] research on the effect of capital, labor, and land area on the amount of Arabica coffee production in Kintamani district Bangli regency stated that capital has a positive effect on the amount of coffee production.

\section{Rationalization of the Use of Land and Capital Production Factors in the Juwita Hybrid Cayenne Variety Farming in Pringgarata Sub-district, Central Lombok Regency}

From the elasticity of land production amounted to 0.905, the Marginal Physical Product (MPP) of the land was $1,922.90 \mathrm{~kg}$. In the MPP condition is lower than APP and the elasticity of land production is greater than zero and smaller than one $(0<\mathrm{Ep}<1)$, it is said that the use of the land production factor is technically rational (stage II).

The correlation between total product, marginal product, and average product with land production factors as variable production factors and other factors of production remains unchanged can be shown in Figure 1. 


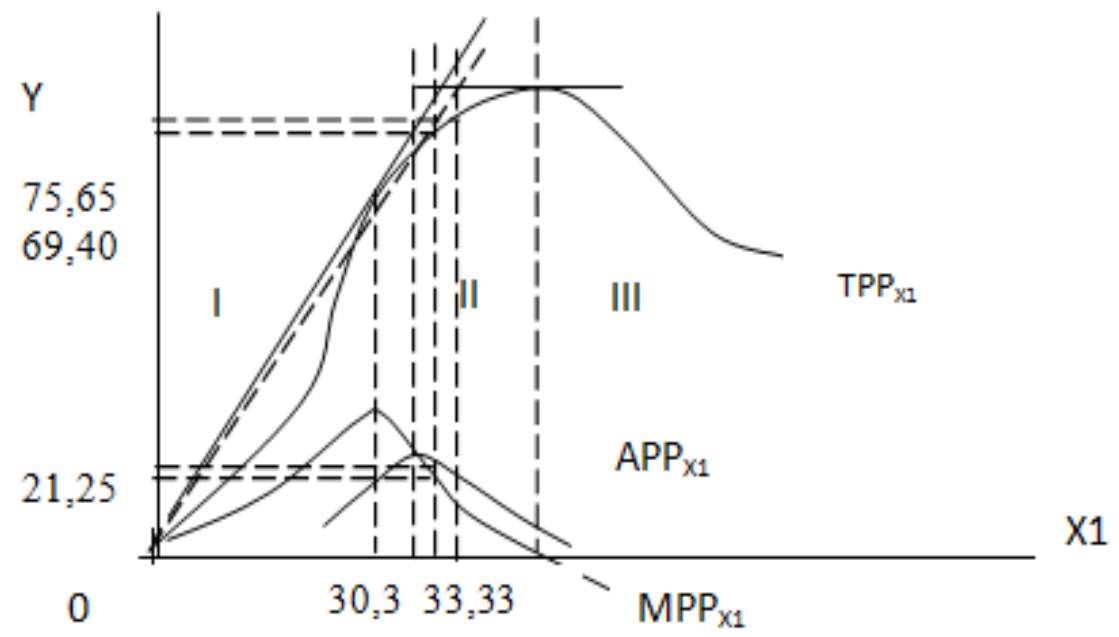

Fig 1:- Correlation between TPP, MPP, and APP with land (X1) as a variable factor and other production factors remain unchanged.

From Figure 1 above, it can be explained, that with a land area of 30.3 acres obtained a total production of Juwita hybrid cayenne variety of as much as $69.40 \mathrm{~kg}$ assuming the other factors of production are fixed and marginal production (MPPX1), and average production (APPX1) $21.25 \mathrm{~kg}$ and $19.23 \mathrm{~kg}$, respectively. If the land production factor is added as much as $1 \%$ to 33.33 acres, then the total production of Juwita hybrid cayenne variety will be 75.65 $\mathrm{kg}$. In addition, the average production (APPX1) of 21.25 $\mathrm{kg}$ is greater than the marginal production (MPPX1) of $19.40 \mathrm{~kg}$ and the total production is in an increased condition or the use of land production factors is in a rational condition.
Furthermore, the elasticity of production of capital production factors is 0.020 assuming other factors of production are still obtained, the average product (APPX1) is $0.001 \mathrm{~kg}$ and marginal production (MPPX2) is 0.00002 $\mathrm{kg}$. In the condition that MPPx 2 is lower than APPx 2 and production elasticity of capital production factors is greater than zero and smaller than $1(0>\mathrm{Ep}>1)$ it is technically said that the use of capital is rational (stage II)

The correlation between total products, marginal products and average products with capital as a variable production factor and other factors of production remains unchanged can be shown in Figure 2.

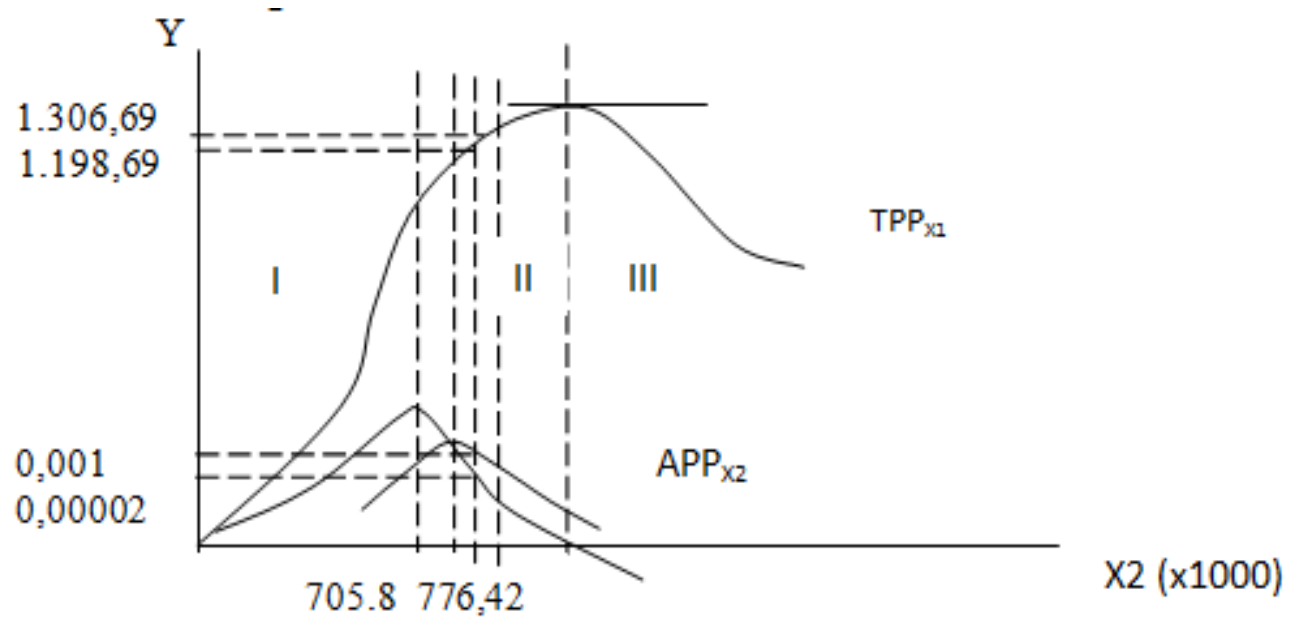

Fig 2:- The correlation between TPP, MPP, and APP with capital (X2) as a variable production factor and other factors of production remains unchanged.

From Figure 2. Above can be explained, that with a capital cost of Rp. 705,833.33 per unit obtained total production of Juwita hybrid cayenne variety of $1,198.69 \mathrm{~kg}$ with an average product (APPX2) of $0.001 \mathrm{~kg}$ and marginal product (MPPX2) of $0.00002 \mathrm{~kg}$. But if capital costs are added as much as $1 \%$ to $\mathrm{Rp}$. 776,416.66 the total production will be $1,306.69 \mathrm{~kg}$.
From Figure 2. it can also be explained, that the average production (APPX2) is higher with marginal production (MPPX2) and the total production of Juwita variety hybrids continues to increase, so the use of capital production factors is in a rational condition. 


\section{CONCLUSIONS AND SUGGESTIONS}

A. Conclusion

From the description of the above discussion it can be concluded the results of the study are as follows:

$>$ The total area of land and capital have a significant effect on the production of Juwita hybrid cayenne varieties cultivated by farmers in Central Lombok regency with an F-count of 255,690 <Sig. 0.05. Furthermore, the land and capital variables are able to explain the production variable of $95 \%(\mathrm{R} 2=0.950)$. But only partially the land has a significant effect on the production of Juwita hybrid cayenne varieties with tcount $(18,975)<$ Sig. 0.05 . While capital has no significant effect on the $95 \%$ level of significance with t-count (0.679)> Sig. 0.05. This condition is caused, because the added capital in the cultivation of Juwita hybrid cayenne varieties farming is not well targeted.

$>$ Both land and capital are partially rational, and their production elasticities are between $0-1$ and are in production area II (stage II).

\section{B. Suggestions}

From the conclusions above, two things can be suggested as follows:

$>$ As long as land is not a limiting factor, it is recommended to farmers in Central Lombok regency to increase the area of their arable land, so that production can be increased. As for capital, it should be used intensively so that its use is appropriate.

$>$ In using the factors of land production and capital for future production activities, it is recommended to farmers in Central Lombok regency to maintain current conditions, i.e. to produce rationally.

\section{REFERENCES}

[1]. Rony Prasetiyo, 2018. Factors Affecting the Production of Red Raw Chili in Nangsri Village, anisrenggo district, Klaten Regency, repository.umy.ac.id

[2]. Katarina Bebe and Werenfridus Taena (2018). Factors That Influence Production of Red Raw Chili Farming in Tapenpah Village, Insana Subdistrict, North Central Timor Regency, http://savana-cendana.id

[3]. Anonymous, 2012. Development of Food Crop Agriculture. Central Lombok Regency

[4]. Agus Juniartha, I Wayan, 2017. Analysis of Efficiency and Productivity of Cabain Rawit (Capsium Frustescens L) Farming of Juwita Varieties in Pringgarata District, Central Lombok Regency, Thesis of Faculty of Agriculture, Mahasaraswati University, Mataram.

[5]. Juliansyah Noor, 2011. Research Methodology, Thesis, Thesis, Dissertation \& Scientific Work, Kencana Prenada Media Group, Jakarta

[6]. Soekartawi, 1987. Basic Principles of Agricultural Economics, Theories and Applications, CV. Rajawali, Jakarta
[7]. Rowland Bismakrk F. Pasaribu,? Classical Assumption Test, http://www.rowlandpasaribu.files.wordpress.com.

[8]. Soekardono, 1986. Diktat Lecture on Agricultural Production Economics, Division of Economics and Education Faculty of Animal Husbandry, University of Mataram

[9]. Hafidh, Muhammad, 2009. The Effect of Labor, Capital and Land Area on Rice Field Production. http://lib.unnesac.id

[10]. Yordy, Giselius, 2017. Analysis of Factors Affecting Arabica Coffee Production in South Sulawesi, eprint.umm.ac.id

[11]. Utami Dewi, Ida Ayu Nyoman and Yuliarmi, 2017. Effect of Capital, Labor and Land Area on the Amount of Arabica Coffee Production in Kintamani Subdistrict, Bangli Regency. Ojs.unud.a.id 